\title{
Evaluation of sperm quality of Erythrolamprus poecilogyrus sublineatus (Cope, 1860) (Serpentes, Dipsadidae)
}

\author{
A. C. Silva ${ }^{a}$, A. S. Varela Junior ${ }^{b}$, T. F. Cardoso ${ }^{b}$, E. F. Silva ${ }^{b}$, D. Loebmann ${ }^{b}$ \\ and C. D. Corcini ${ }^{a *}$ \\ ${ }^{a}$ Center for Research and Education in Animal Reproduction, Faculdade de Veterinária, Universidade Federal de \\ Pelotas - UFPel, Campus Universitário, s/n, CEP 96160-000, Capão do Leão, RS, Brazil \\ 'Institute of Biological Sciences, Universidade Federal do Rio Grande - FURG, Campus Carreiros, \\ Av. Itália, Km 8, Bairro Carreiros, CEP 96203-900, Rio Grande, RS, Brazil \\ *e-mail: corcinicd@gmail.com
}

Received: November 6, 2015 - Accepted: May 12, 2016 - Distributed: August 31, 2017

(With 1 figure)

\begin{abstract}
Erythrolamprus poecilogyrus sublineatus (Cope, 1860) is a species widely distributed in the Pampa Domain, occurring in Rio Grande do Sul, Argentina and Uruguay. In the coastal region of southern Brazil this is one of the most abundant snake's species. The purpose of the present study is to describe the techniques of sperm evaluation in vitro for E. poecilogyrus sublineatus. After laparatomy the efferent vases were collected and the semen was diluted in $1 \mathrm{ml}$ Beltsville Thawing Solution. The characteristics of motility, membrane integrity, mitochondria, acrosome, DNA, cell viability and cellular functionality were evaluated. Fluorescent probes were used for the evaluation of sperm structure in epifluorescence microscope. With the techniques described, it was possible to identify intact and injured cells, enabling the determination of cell characteristics for the spring season (October and November). It was observed in the analyses that $80 \%$ of sperm cells were mobile and that $84.1 \pm 8.0 \%$ of sperm membranes were intact. The standards found were of $48 \pm 13.8 \%$ of intact acrosome, $73.6 \pm 6.0$ of integrity DNA and of $91.8 \pm 4.0$ of functional mitochondria. Thus, these values from the sperm analysis can be used as standards for Erythrolamprus poecilogyrus sublineatus.
\end{abstract}

Keywords: sperm quality, snakes, Brazil.

\section{Avaliação da qualidade seminal de Erythrolamprus poecilogyrus sublineatus (Cope, 1860) (Serpentes, Dipsadidae)}

\section{Resumo}

Erythrolamprus poecilogyrus sublineatus (Cope, 1860), é uma espécie amplamente distribuída no Domínio Pampa, ocorrendo no Rio Grande do Sul, Argentina e Uruguai. Na região costeira do extremo sul do Brasil essa é uma das serpentes consideradas mais abundantes. O objetivo deste estudo é descrever as técnicas de avaliação espermática in vitro para E. poecilogyrus sublineatus. Após laparatomia os vasos eferentes foram coletados e o sêmen diluído em $1 \mathrm{ml}$ Beltsville Thawing Solution. Foram avaliadas as características de motilidade, integridade de membrana, mitocôndria, acrossoma, DNA, viabilidade celular e funcionalidade celular. Foram utilizadas sondas fluorescentes para avaliação das estruturas espermática em microscópio de epifluoescência. Com as técnicas descritas foram possível identificar células integras e lesadas, podendo determinar as características celulares para o período de primavera (outubro e novembro). Nas análises foi observado que $80 \%$ das células espermáticas estavam móveis e que $84,1 \pm 8,0 \%$ das membranas espermáticas estavam íntegras. Os padrões encontrados para foram de $48 \pm 13,8 \%$ de acrossoma íntegro, 73,6 \pm 6,0 de DNA íntegro e de 91,8 \pm 4,0 de mitocôndria funcional. Desta forma, esses valores das análises espermáticas podem ser utilizados como padrão para Erythrolamprus poecilogyrus sublineatus.

Palavras-chave: qualidade espermática, serpente, Brasil.

\section{Introduction}

Currently, the biggest obstacle for the success in reproduction of wild animals in captivity is the lack of knowledge of basic information about most species, including aspects on their reproductive biology (Swanson,
2006). Assisted reproduction in reptiles is still underused, due to the little information about the methods of collecting, spermatic evaluation and cellular structure or artificial insemination (Mattson et al., 2007; Zacariotti et al., 2007). 
Dipsadidae comprises the largest group of living snakes, with more than 1,700 living species distributed in all continents except the Antarctic. This family inhabits all terrestrial environments and substrates (Lema, 2002). In Brazil 245 species are recorded, representing almost $75 \%$ of snake species that occur in the country (Bérnils and Costa, 2012).

Snakes have great importance for their ecological role, i.e., they are responsible for population controlling of animals that provide health or economic risks if they become pests (uncontrolled increase in the number of individuals) as, for example, some species of invertebrates to agriculture and mice for humans. Erythrolamprus poecilogyrus sublineatus (Cope, 1860) is one of the most abundant Dipsadidae species found in the coastal plain of Rio Grande do Sul, Brazil (Correa et al., 2016). This species occurs in a variety of habitats, including wetlands, fields, forest and dunes formations, besides of urbanized areas and patches of eucalyptus.

Regarding its diet this species prey on amphibians fish and small lizards. It is oviparous, depositing from 3 to 12 eggs which remain buried in the sand around $5 \mathrm{~cm}$ in depth (Achaval and Olmos, 2003; Quintela et al., 2006; Quintela and Loebmann, 2009).

In male snakes, the testicles communicate with the cloaca by the vas deferens, which show macroscopic characteristics like tubes coiled in sexually mature species and in immature species they have smooth pipes, which terminate in the genital papillae. The efferent ducts are distributed along the entire length of the epididymis (Volsøe, 1944) to the testis. The copulatory organs in males are called hemipenes and are located within the tail. The reproductive organs of snakes (as well as other paired organs) are asymmetric, being the most cranial and larger of the left side than those on the right sides. In males, the increased size and weight of the testicles help in spermatogenesis (Volsøe, 1944) and the increase in diameter of the vas deferens is a reproductive strategy that reflects the sperm storage (Yokoyama and Yoshida, 1993).

According to Almeida-Santos et al. (2004) testicular re-growth occurs in early spring, due to increase of temperature, which promote spermatogenesis. Thus when temperatures are low there is a reduction in production, where there is only stored sperm.

The objective of the study is to evaluate the ejaculation of E. poecilogyrus sublineatus according to the technical standards of sperm in vitro evaluation.

\section{Material and Methods}

Collection of individuals as well as euthanasia procedures was authorized Instituto Chico Mendes de Conservação da Biodiversidade (SISBIO 32620).

\subsection{Collection and procedures}

Six adult male of E. poecilogyrus sublineatus were collected at Cassino Beach, located at municipality of Rio Grande, state of Rio Grande do Sul, Brazil ( $52^{\circ} 07^{\prime} \mathrm{W}$ $\left.32^{\circ} 09^{\prime} \mathrm{S}\right)$. Semen collections were conducted in the spring
(October and November). The animals were euthanized with an intramuscular injection in the 2 nd and 3 rd cervical region with $2 \mathrm{~mL}$ of the anesthetic thiopental. The efferent vessels were collected and diluted semen in $1 \mathrm{ml}$ BTS (Beltsville Thawing Solution), consisting of $37 \mathrm{~g}$ glucose (G5400, $\geq 99 \%$ Sigma), 6 g of sodium citrate dihydrate (W302600, $\geq 99 \%$, Aldrich), $1.25 \mathrm{~g}$ of sodium bicarbonate (S5761, $\geq 99,5 \%$, Sigma), $1.25 \mathrm{~g}$ of ethylenediamine tetracetate (E4884, 99.0-101.0\%, Sigma-Aldrich) and $0.9 \mathrm{~g}$ of potassium chloride (P8041, 99\%, Sigma) in 1 liter of distilled water (Pursel and Johnson 1975).

\subsection{Seminal reviews}

The motility was determined by the percentage of motile cells identified in the microscopic field at 200x magnification with motility scale $(0-100 \%)$. For this analysis, it was not necessary to heat the blade, because it has been found that cells were immobile when the temperature properties was above $30^{\circ} \mathrm{C}$ (Zacariotti et al., 2007).

For the assessment of the acrosome, the fluorescence probe FITC-PSA was evaluated in the epifluorescence microscope at 400X magnification (BX-51, Olympus, Tokyo- Japan). Acrosome evaluation was evaluated by the presence or absence of green coloration, besides conformation of the region whereas this part when the green color and the membrane is continuous. This stains the sperm that lack the acrosome integrity (Graham, 2001). For the completion of hypoosmotic shock the semen was incubated for $10 \mathrm{~min}$ at $24{ }^{\circ} \mathrm{C}$ in a fructose solution with osmolality of $150 \mathrm{mOsm}$. After this period, 200 cells were counted from which they were classified as coiled tails or not. After the number of cells was decreased, the ones that had coiled tail of the normal morphology and then the percentage of cells with functional membrane was carried out. When sperm cells are exposed to hiposmotics conditions in an attempt to reach osmotic equilibrium, there is a large influx of water into the cell, which leads to a large increase in hydrostatic pressure (Jeyendran et al., 1984). Such intracellular changes tend to promote folding tail indicating that the plasma membrane had the full functionality (Dell'aqua Junior et al., 2002). The analysis of sperm concentration per $\mathrm{mL}$ was assessed after dilution of $2 \mu \mathrm{L}$ of solution of sperm to $998 \mu \mathrm{L}$ of $10 \%$ buffered formalin solution of semen was evaluated by counting in a Neubauer chamber (Zacariotti et al., 2007).

The assessment of membrane integrity of spermatozoa (Figure 1) was performed using fluorescent probes carboxyfluorescein diacetate (C5041- 95\%, Sigma) and propidium (P4170, $\geq 95 \%$, Sigma) in epifluorescence microscope (Olympus, BX 5, Tokyo- Japan) under the magnification of $400 \mathrm{x}$, with excitation filter wavelength of $525 \mathrm{~nm}$. In each blade, 200 sperms were classified according to their staining. In intact sperm the staining observed was green due to the passage of carboxyfluorescein diacetate across the plasma membrane undergoing a process of hydrolyzing transforming it into free carboxyfluorescein which shows the characteristic emission of green fluorescence. In the case of sperm plasma membrane that had lesion, 
the staining observed was red or green and red due to the propidium fact that had penetrated inside the cell, blushing the genetic material of iodide (Silva and Gadella, 2006).

The integrity of the mitochondria was performed by staining with fluorescent Rhodamine 123 (83702, $\geq 95 \%$, Sigma) in epifluorescence microscope under the magnification of $400 \mathrm{x}$, with excitation filter wavelength of $488 \mathrm{~nm}$ (Silva et al., 2009). In each blade 200 sperm cells were counted, which were classified according to intact mitochondria (stained) or injured (translucent) staining, and the final value was the proportion between intact cells and total cells counted converted to percentage (Silva et al., 2009; Gravance et al., 2001).

DNA integrity was assessed by acridine orange probe (A6014, Sigma) in dry blade in an epifluorescence microscope under magnification of $400 \mathrm{x}$, with excitation filter wavelength of $525 \mathrm{~nm}$. The sperm that emits green fluorescence in the head will be classified as normal (double-stranded DNA) and when emitting red or yellow fluorescence it was classified as denatured (mono-stranded DNA) (Gravance et al., 2001; Silva and Gadella, 2006).

Sperm morphology was analyzed using swabs with semen diluted in formalin (4\%) buffered saline at the ratio of 1:2000 (semen: formaldehyde buffered saline). The smears were stained using rose bengal. A total of 200 cells were evaluated in an optical microscope under
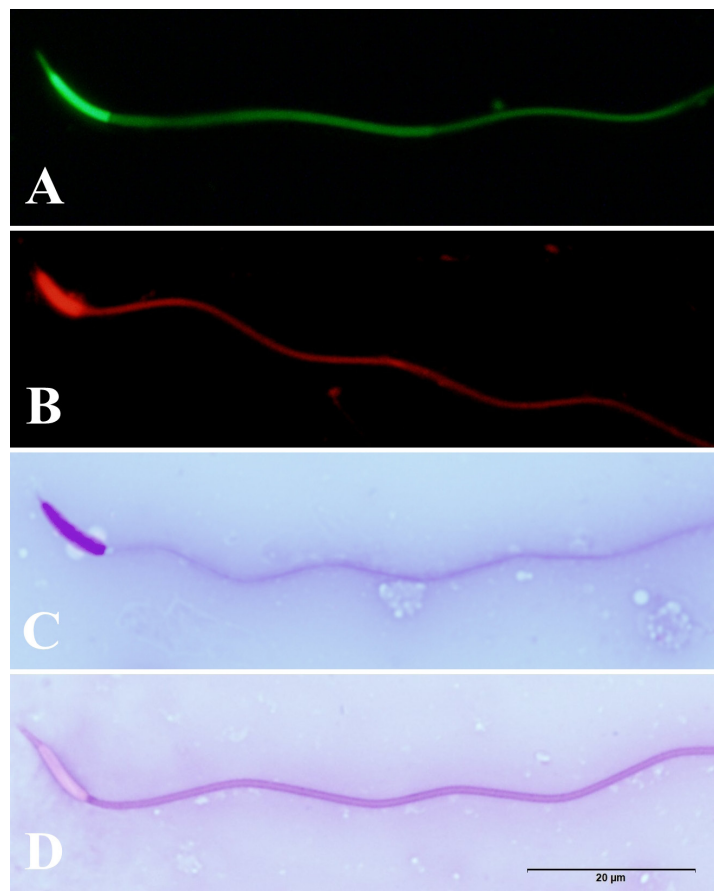

Figure 1. The viability of snake sperm was evaluated membrane integrity of spermatozoa was performed using fluorescent probes carboxyfluorescein diacetate (A) and propidium (B) in epifluorescence microscope. A light microscope (1000X) following eosin-nigrosin (C) staining and giemsa (D). 1000x magnification, and classified as normal and with pathology (coiled tail) (Yokoyama and Yoshida, 1993).

\subsection{Statistical analysis}

Descriptive statistical analysis was performed to obtain the mean, with maximum and minimum of each variable analyzed using Statistix 9.0 software.

\section{Results and Discussion}

Evaluation of sperm quality in vitro is an important step in the process of conservation of the species in or ex situ. In seeking to optimize assisted reproduction techniques it becomes essential to establish values for useful parameters to evaluate the reproductive power of populations of Erythrolamprus poecilogyrus sublineatus. It was observed that in most of the evaluated parameters there was a wide variation among males (Table 1). Parameters such as motility had a $20 \%$ variation between the maximum and the minimum. This demonstrates that factor is variable is imprecise an estimator sperm quality of males. Table 1 the variables membrane integrity and acrosome the variation was almost $50 \%$ between the maximum and minimum.

These differences between individuals observed at the beginning of the breeding season, spring, makes it important to understand the individual variability in addition to reproductive strategies issues such as competition sperm, reproductive cycles, mating systems, sperm storage and fertilization.

These probes used for acrosome integrity, membrane (Figure 1) and DNA were not reported for the evaluation of sperm quality in vitro snakes. It was observed these

Table 1. Mean values (minimum and maximum) of the seminal characteristics snake E. poecilogyrus sublineatus, during the spring, in southern Brazil ( $\mathrm{n}=6$ samples).

\begin{tabular}{|c|c|c|c|}
\hline In vitro analysis & Mean & Minimum & Maximum \\
\hline $\begin{array}{l}\text { Intact acrosome } \\
(\%)\end{array}$ & 48 & 10 & 98 \\
\hline $\begin{array}{l}\text { Functional } \\
\text { membrane (\%) }\end{array}$ & 30 & 10 & 48 \\
\hline $\begin{array}{l}\text { Concentration } \\
\text { (cells/ml) }\end{array}$ & 330,000 & 217,500 & 580,000 \\
\hline Intact DNA (\%) & 73 & 51 & 95 \\
\hline $\begin{array}{l}\text { Intact membrane } \\
(\%)\end{array}$ & 84 & 57 & 100 \\
\hline $\begin{array}{l}\text { Intact } \\
\text { mitochondria } \\
(\%)\end{array}$ & 92 & 79 & 100 \\
\hline $\begin{array}{l}\text { Sperm with } \\
\text { normal } \\
\text { morphology (\%) }\end{array}$ & 92 & 82 & 99 \\
\hline $\begin{array}{l}\text { Sperm with } \\
\text { coiled tail (\%) }\end{array}$ & 8 & 1 & 18 \\
\hline Viable cells (\%) & 80 & 67 & 92 \\
\hline $\begin{array}{l}\text { Sperm motility } \\
(\%)\end{array}$ & 80 & 70 & 90 \\
\hline
\end{tabular}


probes have affinity for glycolipids found in spermatozoa can be used for verification of damage caused in the cell, or contamination or variations of male sexual maturity. In addition, it was noticed that the assessment of sperm morphology overestimates the male quality, the only condition was found folded tail. In search of a better standardization or more qualified information, it is important for understanding of sperm structures and the changes that may suffer due to environmental impacts to which the animals are submitted.

The species Crotalus ruber (Viperidae, Crotalinae) during the spring showed a motility of $68.1 \%$, however $96.4 \%$ of the evaluated sperm showed acrosome intact cells when evaluated by diaminobenzidine (DAB) (Zacariotti, 2008). When we use the FIT-Lectin staining an average percentage of $48 \%$ was observed, due to be considered in addition to stain, the conformation of the acrosome. The paucity of information regarding patterns of snake sperm quality makes comparison between the data found. Comparing snakes of different environments can generate hypotheses, test existing theories and draw attention to the unique properties of each entity being compared.

\section{Conclusion}

This work demonstrates the results found in the ejaculation of snakes of the species E. poecilogyrus sublineatus.

\section{Acknowledgements}

We would like to acknowledge the Coordenação de Aperfeiçoamento de Pessoal de Ensino Superior. C.D. Corcini (number 306356/2014-7) and A.S. Varela (number 307195/2015-7) are research fellows from the Brazilian Conselho Nacional de Desenvolvimento Científico e Tecnológico (CNPq). We would also like to thank the members of the Comparative Animal Reproduction (Universidade Federal do Rio Grande, Rio Grande, RS, Brazil) group for their assistance.

\section{References}

ACHAVAL, F. and OLMOS, A., 2003. Anfibios y reptiles del Uruguay. Montevideo: Ed. Graphis Impresora, pp. 136.

ALMEIDA-SANTOS, S.M., LAPORTA-FERREIRA, I.L., ANTONIAZZI, M.M. and JARED, C., 2004. Sperm storage in males of the snake Crotalus durissus terrificus (Crotalinae: Viperidae) in southeastern Brazil. Comparative Biochemistry and Physiology. Part A, Molecular \& Integrative Physiology, vol. 139, no. 2, pp. 169-174. http://dx.doi.org/10.1016/j. cbpb.2004.08.004. PMid:15528165.

BÉRNILS, R.S. and COSTA, H.C., 2012. Brazilian reptiles: list of species. Version: 2012.2. São Paulo: Sociedade Brasileira de Herpetologia.

COPE, E.D., 1860. Catalogue of the Colubridae in the Museum of the Academy of Natural Sciences of Philadelphia, with notes and descriptions of new species. Part II. Proceedings Academy Natural Sciences, vol. 12, pp. 241-266.
CORREA, D. N., QUINTELA, F. M., and LOEBMANN, D., 2016. Feeding ecology of Erythrolamprus jaegeri jaegeri (Günter, 1858) and Erythrolamprus poecilogyrus sublineatus (Cope, 1860 ) in the coastal zone of Subtropical Brazil (Serpentes, Dipsadidae). Anais da Academia Brasileira de Ciências, vol. 88, no. 1, pp. 1-12. http://dx.doi.org/10.1590/00013765201520140570 .

DELL'AQUA JUNIOR, J.A., PAPA, F.O., ZAHN, F.S., ALVARENGA, M.A. and LEONARDO, H., 2002. Novo teste osmótico de avaliação da integridade da membrana plasmática de sêmen congelado eqüino. Revista Brasileira de Reprodução Animal, vol. 26, pp. 189-191.

GRAHAM, J.K., 2001. Assessment of sperm quality: a flow cytometric approach. Animal Reproduction Science, vol. 68, no. 3-4, pp. 239-247. http://dx.doi.org/10.1016/S03784320(01)00160-9. PMid:11744268.

GRAVANCE, C.G., GARNER, D.L., MILLER, M.G. and BERGER, T., 2001. Fluorescent probes and flowcytometry to assess rat sperm integrity and mitochondrial function. Reproductive Toxicology, vol. 15, no. 1, pp. 5-10. http:// dx.doi.org/10.1016/S0890-6238(00)00113-1. PMid:11137373.

JEYENDRAN, R.S., VAN DER VEN, H.H., PEREZ-PELAEZ, M., CRABO, B.G. and ZANEVELD, L.J., 1984. Development of an assay to assess the functional integrity of the human sperm membrane and its relationship to other semen characteristics. Journal of Reproduction and Fertility, vol. 70, no. 1, pp. 219228. http://dx.doi.org/10.1530/jrf.0.0700219. PMid:6694140.

LEMA, T., 2002. Os répteis do Rio Grande do Sul: atuais e fósseis - biogeografia - ofidismo. Porto Alegre: Ed. EDIPUCRS. $264 \mathrm{p}$.

MATTSON, K.J., VRIES, A.D., MCGUIRE, S.M., KREBS, J., LOUIS, E.E. and LOSKUTOFF, N.M., 2007. Successful artificial insemination in the corn snake (Elaphegutatta), using fresh and cooled semen. Zoo Biology, vol. 26, no. 5, pp. 363369. http://dx.doi.org/10.1002/zoo.20144. PMid:19360586.

PURSEL, V.G., JOHNSON, L.A., 1975. Freezing of boar spermatozoa: fertilizing capacity with concentrated semen and a new thawing procedure. Journal of Animal Science, vol. 40, no. 1, pp. 99-102. PMID: 1110222.

QUINTELA, F.M. and LOEBMANN, D., 2009. Guia ilustrado: os répteis da região costeira do extremo sul do Brasil. Pelotas: USEB, pp. 88

QUINTELA, F.M., LOEBMANN, D. and GIANUCA, N.M., 2006. Répteis continentais do Município de Rio Grande, Rio Grande do Sul, Brasil. Biociencias, vol. 14, no. 2, pp. 180-188.

SILVA, P.F.N. and GADELLA, B.M., 2006. Detection of damage in mammalian sperm cells. Theriogenology, vol. 65 , no. 5 , pp. 958-978. http://dx.doi.org/10.1016/j.theriogenology.2005.09.010. PMid:16242762.

SILVA, S.V.; BATISTA, A.M.; COLETO, Z.F. and GUERRA, M.M.P., 2009. Diferentes métodos e técnicas na avaliação espermática: uma breve revisão. Ciência Veterinária nos Trópicos, vol. 12, pp. 1-15.

SWANSON, W., 2006. Application of assisted reproduction for population management in felids: the potential and reality for conservation of small cats. Theriogenology, vol. 66, no. 1, pp. 
49-58. http://dx.doi.org/10.1016/j.theriogenology.2006.03.024. PMid:16650889.

VOLSØE, H., 1944. Seasonal variation of the male reproductive organs of Viperaberus (L.). Spolia Zoology Museum Hauniensis, vol. 5, pp. 1-157.

YOKOYAMA, F. and YOSHIDA, H., 1993. Thereproductive cycle of the male habu, Trimeresurusflavoviridis. The Snake, vol. 25 , pp. 55-62.
ZACARIOTTI, R.L., 2008. Avaliação reprodutiva e congelação de sêmen em serpentes. São Paulo: Universidade de São Paulo. 98 p. Tese de doutorado em Medicina Veterinária.

ZACARIOTTI, R.L., GREGO, K.F., FERNANDES, W., SANT'ANNA, S.S. and GUIMARÃES, M.A.B.V., 2007. Semen collection and evaluation in free-ranging Brazilian rattlesnakes (Crotalus durissus terrificus). Zoo Biology, vol. 26, no. 2, pp. 155-160. http://dx.doi.org/10.1002/zoo.20126. PMid:19360568. 